\title{
DIREITO E ECONOMIA: RUMO A UMA CONCEPÇÃO DIALÉTICA-REALISTA PARA ALÉM DO “LAW AND ECONOMICS"
}

\author{
LAW AND ECONOMICS BEYOND "LAW AND ECONOMICS" . TOWARDS A \\ DIALECTIC-REALIST CONCEPTION
}

\author{
José Antonio Pontes \\ Faculdade de Campinas -Facamp - São Paulo- Brasil
}

\begin{abstract}
Resumo: Para que as relações entre direito e economia componham um movimento realista do direito, é necessário a superação do modelo Law \& Economics. A busca da eficiência aparece nele como algo racional, sem elementos da realidade segundo categorias dialéticas, seja de Hegel, seja de Marx, sem a riqueza epistêmica das relações entre espírito e matéria. Os elementos históricos universais concretos que subjazem a toda racionalidade econômica no capitalismo global restam, portanto, ignorados. Qualquer programa de pesquisa das influências entre direito e economia deve atentar para as realidades locais e históricas para que seus resultados fomentem as possíveis ações emancipatórias. O movimento do nuevoconstitucionalismo-latino-americano parece ser uma clara manifestação que comprova a necessidade de uma concepção dialético-realista do direito para superação do Law and Economics e dos neoconstitucionalismos.
\end{abstract}

Palavras-chave: Direito, economia, dialética, neoconstitucionalismo.

Abstract: For the relationship between economics and law compose a realistic movement of law, it is necessary to overcome the model os Law \& Economics. The pursuit of efficiency appears as something rational, without elements of reality according to dialectical categories, neither Hegel's nor Marx's ones, remaining without the richness epistemic relations between spirit and matter. The universal concrete of historical elements that underlie all economic rationality in global capitalist are left, therefore, ignored. Any research program abaotu the influences between economics and Law should pay attention to local realities and historical so that its results may foster emancipatory potential actions. The nuevoconstitucionalismo-latino-americano seems to be a clear demonstration that proves the need for a realistic-dialectical concepto of Law, overcoming Law and Economics and the so called new constitucionalism.

Key-words: Law, economics, dialectics, new constitutionalism.

\section{INTRODUÇÃO}

Em uma tradução literal, law and economics (L\&E) quer dizer direito e economia ou análise econômica do direito, movimento que teve origem nos Estados Unidos e hoje se encontra disseminado em todo o mundo. O enfoque adotado é o estudo do direito do ponto de vista de seus reflexos na economia, em especial

Revista do Direito da UNISC, Santa Cruz do Sul, v.2, n. 46, p. 03-33, maio - ago. 2015. 
aqueles que diretamente interferem na atividade empresarial. Enquanto as primeiras pesquisas estudavam os efeitos das normas no funcionamento do sistema econômico, a geração seguinte utilizou a análise econômica para melhor entender o sistema legal. É comum identificar-se a origem do movimento com um trabalho do economista Ronald Coase que Ihe rendeu um festejado prêmio. Todavia, as propostas do L\&E começaram a ganhar corpo com um livro escrito por Richard Posner (1973) (Univ.Chicago) e um artigo sobre responsabilidade civil de Guido Calabresi (1961) (Univ.Yale) escrito com Douglas Melamed (1972), gerando grandes movimentos de aproximação entre os juristas e economistas nas décadas de 60 e 70 do século XX.

Vejamos alguns traços originais com o multi-citado artigo de Coase (publicado em 1960): segundo o "teorema de Coase", sob um regime de perfeita competição, se os "custos de transação" forem iguais a zero, os recursos serão sempre alocados da forma mais eficiente. Mas como ele mesmo reconhece, no mundo real, esses custos nunca são iguais a zero e, por isso, para uma melhor alocação de recursos numa situação ótima, é preciso que se levem em conta os custos de todos os tipos de negócios jurídicos que oneram a atividade econômica. Esses custos, tradicionalmente considerados "externalidades", são tão importantes quanto os custos de produção e, por serem uma teia de relações jurídicas contratuais, forçam a necessidade de seu cuidadoso estudo para uma boa gestão da empresa. $^{2}$

Se, por exemplo, os agentes econômicos levarem a sério os custos dos contratos e de sua violação, as despesas com seguros e com indenizações por responsabilidade civil, os fluxos do capital financeiro e a tributação, bem como os inúmeros regulamentos de agências que limitam a liberdade empresarial, tais como exigências penais, ambientais, consumeristas etc., garantirão maior eficiência aos negócios. (COASE, 1991).

O presente artigo pretende abordar as seguintes questões: quais são os fundamentos da proposta $L \& E$ ? Qual o método adotado? O L\&E realmente apresenta uma metodologia eficiente? Quais são as críticas analíticas de seus fundamentos?

\footnotetext{
${ }^{1}$ No original "costs of transactions".

2 Nas palavras de R. Coase (2008, p.36): "Nós podemos nos referir a uma pessoa que possui terra e que a utiliza como um fator de produção, mas o que, realmente, o proprietário possui é o direito de realizar uma definida lista de ações. Os direitos do proprietário não são ilimitados". COASE, Ronald. O problema do custo social."
}

Revista do Direito da UNISC, Santa Cruz do Sul, v.2, n. 46, p. 03-33, maio - ago. 2015. 
A partir desse diagnóstico inicial, serão propostas críticas dialético-realistas ao $L \& E$, para que haja o relevo das especificidades histórico-concretas e percepção do conceito de fontes materiais, para, diante do surgimento de um nuevoconstitucionalismo-latino-americano, em breve síntese, traçar algumas linhas sobre um programa de pesquisa possível no desenvolvimento do pensamento crítico brasileiro e latino-americano em torno dos conceitos em torno do direito.

\section{OBSERVAÇÕESMETODOLÓGICAS: O NOVO MÉTODO L\&E DE ANÁLISE DO DIREITO}

Os autores associados ao $L \& E$ podem ser identificados como herdeiros do realismo jurídico norte-americano, embora ambos os movimentos teóricos não possam ser considerados uníssonos. ${ }^{3} \mathrm{~A}$ razão é a presença de um lema de raiz: a predição do que as cortes judiciais farão é o critério de definição substancial do direito, destacando a importância dos juízes na renovação da Common Law, cuja regra do stare decisis a muitos parecia um engessamento conceitual que impedia o progresso das ciências jurídicas. Por essa razão, o diálogo que se estabeleceu na filosofia do direito sob influência anglófona, especialmente a partir de H.Hart e R.Dworkin na década de 1970, caminhou ainda pelas sendas do papel dos tribunais na conformação do conceito de direito, mormente diante da descoberta dos princípios e do que farão os juízes diante dos casos difíceis ("what courts will do in hard cases"). ${ }^{4}$

Essa aproximação entre direito e economia trouxe uma primeira inovação metodológica, a influência do direito na economia, pois o L\&E não se limitou a estudar o impacto do direito na economia, mas foi além ao propor que as normas jurídicas sejam analisadas como um "sistema" apto a gerar maior eficiência no mercado.

Nesse sentido, novas categorias jurídicas foram criadas conforme o progresso social econômico (property rules, liability rules, inalienability rules, efficient breach etc.) com o evidente objetivo de influenciar os juízes em decisões futuras para garantir maior eficiência dos mercados em sentido amplo. Por isso, se nota uma

\footnotetext{
${ }^{3}$ Sobre as distinções internas da "escola realista" dos EUA, vide Llewellyn (1962, p. 53-74)

${ }^{4}$ Adaptação, segundo pensamos, do que diria Oliver Wendell Holmes se fosse vivo em 1970.
}

Revista do Direito da UNISC, Santa Cruz do Sul, v.2, n. 46, p. 03-33, maio - ago. 2015. 
segunda inovação metodológica do movimento, a influência da economia no direito, isto é, a identificação de padrões econômicos de decisão racional que influam nas cortes em casos difíceis, liderados, é claro, pelos padrões de eficiência e maximização da riqueza.

Em artigo festejado de Guido Calabresi, notável defensor do movimento, aparecem com mais clareza algumas distinções da racionalidade jurídica tendente a garantir maior eficiência: a distinção entre "property rule" e "liability rule". O exemplo mais citado na literatura do $L \& E$ é o exemplo do poluidor: se o proprietário $\boldsymbol{M}$ polui o rio que banha as terras de outro proprietário $\boldsymbol{K}$, o simples raciocínio unilateral $e$ atrasado do direito de propriedade tradicional daria a $\boldsymbol{K}$ uma série de demandas aptas a anular a atividade de $\boldsymbol{M}$, ou mesmo atingir seus direitos sobre as terras (esse seria o uso das "property rules"). Mas como o proprietário $\mathbf{M}$ pode ser a Monsanto, a situação é diferente: o alto custo dos capitais envolvidos joga luzes sobre o princípio de eficiência, clamando por novos raciocínios "mais razoáveis" que permitam uma divisão dos prejuízos entre as partes conforme suas responsabilidades (e aqui surgiria o novo conceito das "liability rules").

Para ilustrar esse movimento, um dos casos mais citados entre os precedentes norte-americanos é o litígio (case) Spur Industries, Inc. v. Del E. Webb Development Co., em que Spur possuía uma criação intensiva de gado e foi processada pela Webb quando esta criou um empreendimento imobiliário para veraneio na mesma região e se sentiu prejudicada pelos incômodos da criação de gado (dejetos, odores, mosquitos). A corte federal do estado do Arizona decidiu que o direito de propriedade do empreendimento residencial Webb fazia face, em importância, à atividade da indústria Spur e esta só poderia ser responsabilizada se também fosse indenizada por aquela, que aliás, chegou depois. Essa decisão foi considerada paradigma na percepção da força das "liability rules", em detrimento da visão tradicional das "property rules".

Portanto, a proposta do $L \& E$ é relativamente simples: falar em responsabilidade civil no sentido forte dos direitos de propriedade de matriz jusracionalista é muito belo, mas atrasado e pouco eficiente, ao menos se os custos envolvidos num conflito entre proprietários forem altos. É claro que a industrialização e a urbanização dos últimos duzentos anos de capitalismo forçaram alterações nos conceitos de responsabilidade moral e jurídica baseados em Kant, Locke e Jhering. v.2, n. 46, p. 03-33, maio - ago. 2015. 
Qualquer análise da sociologia dos tribunais é capaz de detectar essas mudanças, até mesmo nos países de tradição no direito codificado. ${ }^{5}$ A questão é a ênfase dos autores do movimento $L \& E$ para explicar casos como esse: trata-se de captar as influências econômicas no raciocínio jurídico em torno da propriedade e da responsabilidade civil.

Portanto as características básicas que resumem as teses do $L \& E$ são principalmente três: (1) a tese econômica de que os indivíduos são maximizadores racionais de riquezas; (2) o direito influencia a economia e pode ser instrumento para uma solução ótima dos problemas econômicos e maior eficiência na circulação e no equilíbrio da riqueza; (3) consequentemente, a economia influencia o direito porque tem uma racionalidade que determina alterações nos conceitos jurídicos.

Eis o coração do movimento L\&E no que diz respeito à racionalidade do agir humano, especialmente o jurídico: se o direito é visto como um sistema que visa maximizar a riqueza, alocando os recursos de forma eficiente, é em vista disso que os indivíduos fazem suas escolhas, tanto mais racionais e justas quanto mais levarem em consideração os custos das ações na dinâmica social e econômica.

Essa questão da justiça é enfrentada por Richard Posner, outro festejado autor desse movimento nos EUA. Segundo ele, "justiça" é um termo ambíguo, que comporta diversas interpretações e possui diversos significados: algumas vezes quer dizer justiça distributiva, o apropriado grau de igualdade econômica. Mas como não é possível precisar o que vem a ser "justiça", é possível dizer que "em alguns casos" ela deve ser concebida nos termos práticos do L\&E (POSNER, 1984, p. 131135). Em consequência, Posner (1998) defende que o mais comum sentido de justiça é o de eficiência. Seus argumentos seguem exemplos concretos: quando uma pessoa diz que é injusto retirar a sua propriedade sem compensação, ou quando a justiça falha ao indenizar corretamente a vítima de um acidente provocado por um motorista negligente, estamos exatamente diante de exemplos de uma ineficiente alocação de recursos.

Partindo-se dessas premissas, qualquer ramo do direito passa a ser passível de análise pelos economistas. No direito penal, por exemplo, podemos inferir que o indivíduo decide suas condutas com base no custo/benefício de agir licitamente, pois

\footnotetext{
${ }^{5}$ Em SCHÄFER \& OTT (2008) leem-se algumas notas sobre a evolução dos institutos da responsabilidade civil na Alemanha, com a clara referência aos conceitos de Guido Calabresi.
} 
em determinadas ocasiões pode parecer mais rentável para o indivíduo agir contrariando a lei. Num segundo passo, pode ser mais rentável lutar nos tribunais por uma mudança de paradigma, buscando a alteração daquela norma que torna ilícita uma conduta que seria menos eficiente do ponto de vista econômico. Com exemplos brasileiros, as tendências liberais em processo civil e penal no sentido de tornar mais céleres os procedimentos são tendências consideradas mais racionais exatamente pelos motivos captados pelo L\&E; também os esforços que levaram à reforma da legislação de falências e recuperação de empresas estão intimamente ligados à juridicidade de elementos eminentemente jurídico-econômicos. Outros esforços tem sido feitos em outras áreas, como o direito dos contratos, o direito ambiental, direito regulatório etc.

Mas a essência do $L \& E$ vai além: todas as dimensões espirituais, morais, culturais do homem podem ser monetizadas, dimensionadas em termos utilitaristas e daí em diante se torna possível prever e alterar condutas políticas e jurídicas com eficiência. Por essa razão a análise econômica não se reduz, é claro, ao direito. É notório o trabalho de Gary Becker nesse sentido, outro professor de Chicago laureado internacionalmente por ter feito análise econômica dos comportamentos nas relações de família (adoções e casamentos) e interpessoais (preconceitos), na racionalidade dos crimes etc., que bem poderia perfeitamente ser chamado "family and economics", "crime and economics", "prejudice and economics" e assim por diante. (BECKER, 1957, 1974, 1976).

Por isso Posner (1978) também crê que todas as facetas da vida em sociedade, até mesmo as relações religiosas ${ }^{6}$ e a adoção de crianças admitem uma análise do ponto de vista da alocação eficiente de recursos, causando debates apaixonados ("my baby is not for sale!') que forçaram Posner a se defender dizendo que "não é adepto do livre mercado de bebês". 7

\section{O L\&E REALMENTE APRESENTA UMA METODOLOGIA EFICIENTE?}

Esses exemplos servem para demonstrar que uma racionalização utilitária está por trás de boa parcela, senão da totalidade das regras jurídicas na visão do

\footnotetext{
${ }^{6}$ Para concluir que é legítima a existência de benefícios tributários para as igrejas, até mesmo a vida religiosa teve sua análise econômica. (POSNER, 198, p. 1-13).

${ }^{7}$ Para uma discussão em torno do problema de transformar a adoção de bebês em "commodities" segundo a lógica da maximização eficaz das riquezas, especialmente defendida por Posner, vide: ELISABETH(1978). Contra Posner, ERTMANN (2005) e RADIN (1987).
}

Revista do Direito da UNISC, Santa Cruz do Sul, v.2, n. 46, p. 03-33, maio - ago. 2015. 
L\&E. O lastro concreto em interesses econômicos que traduzem os direitos em pecúnia a se pagar justifica, assim, que o direito busque a eficiência econômica mediante argumentos consequencialistas.

Mas será essa metodologia eficiente? Ainda que analisada aqui em suas linhas gerais, a doutrina internacional e brasileira sobre o tema tem respostas afirmativas, no sentido de que as análises de custos de oportunidade, respostas a incentivos, liberdade de barganha, busca de equilíbrio e racionalidade maximizadora compõem um método robusto de análise do direito:

Em resumo, é exatamente nesse aspecto que a Análise Econômica do Direito (...) é um método de análise robusto o suficiente para o levantamento e teste de hipóteses sobre o impacto de uma determinada norma (estrutura de incentivos) sobre o comportamento humano, o que Ihe atribui um caráter empírico ausente no paradigma jurídico atual. (...) porque é flexível o suficiente para adaptar-se a situações fáticas específicas (adaptabilidade) e incorporar contribuições de outras searas (inter e transdisciplinariedade), o que contribui para uma compreensão mais holística do mundo e para o desenvolvimento de soluções mais eficazes para problemas sociais em um mundo complexo [...] ( GICO, 2010, p. 16)

É notório que o $L \& E$ assume cada vez mais importância na pesquisa jurídica mundial. Uma simples busca na internet pelos termos "associação, departamento, direito e economia" mostra uma profusão astronômica de instituições que elaboram pesquisa em faculdades de direito e ONGs lideradas por juristas que se autodenominam seus defensores. Todavia não há clareza sobre o que muitas dessas pesquisas têm feito de especificamente jurídico, ainda que adotemos uma linha interdisciplinar nas relações entre economia e direito ${ }^{8}$. Daí que coletar informações sobre os fluxos de capitais em nível macroeconômico ou dos "custos de transação" em nível microeconômico é uma tarefa de eficiência dos agentes econômicos em sentido amplíssimo já há pelo menos quatro séculos, sob influência do pragmatismo político-econômico desde o mercantilismo. ${ }^{9}$ Sob um ponto de vista aqui defendido, para boa parte dos programas de pesquisa em $L \& E$ ao redor do mundo, ainda não há consciência clara de que os movimentos captados por R.Coase foram um esforço de pesquisa marcadamente econômica, especificamente nos negócios privados.

\footnotetext{
${ }^{8}$ Alguns exemplos do Brasil: Latin American and Iberian Law and Economics Association (Alacde), Associação Brasileira de Direito e Economia, Centro de Pesquisa em Direito e Economia (CPDE), da Fgv Direito Rio, Associação Paranaense de Direito e Economia, Academia Internacional de Direito e Economia, AMDE Associação Mineira de Direito e Economia, além de incontáveis programas de pós-graduação com o título Direito e Economia ou L\&E.

${ }_{9}$ A questão da origem desse pensamento é secundária, mas a relação entre direito e economia é bem mais antiga, a ponto de Ejan Mackaay, identificar origens dessa relação em Maquiavel ao ver em seus estudos a concepção de um ser humano que faz escolhas racionais de ponderação entre custos e benefícios. MACKAAY (2012).
}

Revista do Direito da UNISC, Santa Cruz do Sul, v.2, n. 46, p. 03-33, maio - ago. 2015. 
Ainda assim, o coração do "teorema de Coase" não passou sem acusações de tautologia ou equívocos, na tentativa de ofuscar sua medalha dourada do prêmio Nobel. ( USHER, 1998)

Em inúmeros artigos científicos o direito parece caminhar a reboque e pouco é feito em torno dos conceitos típicos da ciência jurídica (justiça, validade, eficácia, interpretação etc.). Os efeitos de uma determinada legislação tributária sobre o mercado, ou sobre a estrutura de custos dos negócios no setor agrícola, por exemplo, comportam um método de estudo que em nada se diferencia do método econômico tradicional; a busca de eficiência aqui se concentra em torno da mãe de todas as vaguezas terminológicas do setor, o mercado, e sua filha predileta, a governança corporativa, sempre capitaneados, em larga medida, pelo individualismo metodológico à M.Weber, J.Schumpeter e F.Hayek.

Quando trata diretamente dos conceitos jurídicos, na área de responsabilidade civil, por exemplo, a análise econômica das decisões judiciais parece renomear os fenômenos jurídicos, ou seja: por qual razão o caso Spur vs. Webb citado acima não poderia simplesmente ser explicado com os conceitos tradicionais da responsabilidade civil? Não seria mais simples dizer que as alterações jurídicas acompanham as alterações econômicas? Não seria uma petitio principii ver essa evolução dos conceitos como uma prova da eficiência inerente ao regime de mercado? Por fim, a análise das causas materiais dessas transformações não seria mais interessante para captar as determinações valorativas da economia na formação dos padrões de decisão descritos como tipicamente jurídicos?

Também no direito dos contratos, em que as partes supostamente podem negociar valores em igualdade de condições, houve grandes desenvolvimentos da pesquisa em $L \& E$, talvez porque a performance da equivalência mercantil seja particularmente aguda nesse ramo negocial. (VELOSO). Todavia, quando se discute, por exemplo, o conceito de "inadimplemento eficiente" (efficient breach) que é a possibilidade de rompimento contratual diante de circunstâncias imprevisíveis das variações de mercado, já há muito tempo tem havido críticas de que essa eficiência parece se dissolver em questões semânticas. ${ }^{10}$ Mais recentemente, outras

\footnotetext{
10 "a regra de inadimplemento eficiente é ineficiente em seus próprios termos. Nem ela nem a análoga regra de conversão eficiente têm o efeito desejado de minimizar seja o número de transações seja, mais decisivamente, o v.2, n. 46, p. 03-33, maio - ago. 2015.
} 
vozes hereditárias $\left({ }^{*}\right)$ do movimento surgem defendendo que $O L \& E$ tem trazido resultados módicos na área. ${ }^{11}$

Por fim, diante das complexas relações entre direitos privados e públicos que nublam essa clássica distinção, os estudos da destinação ineficiente de recursos em políticas previdenciárias ou assistenciais, os modelos de gestão de políticas públicas de cunho social e regulação da atividade empresarial e as práticas lato sensu de eficiência das políticas econômicas em nível governamental, quando não completamente ausentes da maioria dos trabalhos, podem no máximo dar informações locais sobre os efeitos das "políticas-jurídicas" de governo mediante dados estatísticos e denunciar suas incongruências, sem ter em mente outras categorias necessárias para relacionar os movimentos universais do capital e os aspectos histórico-regionais em análise, o que desperta o senso crítico para uma necessária virada das concepções metodológicas no estudo das relações entre direito e economia.

\section{OUTRAS CRÍTICAS ANALÍTICAS DE SUEUS FUNDAMENTOS}

Uma das mais conhecidas objeções ao $L \& E$ gira em torno das "teorias da justiça" presentes em várias democracias constitucionais contemporâneas. Os reducionismos do $L \& E$ fazem concluir que o direito não estaria mais a serviço da justiça, mas sim a serviço do lucro, se aproximando daquilo que o mercado dita. Nesse ponto, toda ética do movimento parece restrita à ética utilitarista de Jeremy Bentham. (GASPERIN, 2006)

Posner (1973), após inúmeros debates com nomes de peso no cenário acadêmico dos EUA ${ }^{12}$, ressalvou que a "justiça" vai além da eficiência. Neste sentido, a eficiência faz a justiça, mas não se iguala a ela. Sua proposta caminha no

\footnotetext{
montante total dos custos de transação. Na verdade, essas regras podem muitas vezes levar a um aumento dos custos totais de transação". (FRIEDMANN, 1989, p. 1-24 tradução nossa).

${ }_{11} \mathrm{Na}$ atualidade, lemos que tem havido moderações nas "reivindicações sobre o valor da análise econômica para compreender outras áreas do Direito", a digressão é de $\left(^{*}\right)$ Eric Posner, filho de Richard Posner: "E a análise econômica proporciona pouca orientação normativa para reformar o direito contratual. Os modelos que foram propostos na literatura ou focam-se sobre pequenos aspectos do comportamento contratual ou fazem da doutrina ótima uma função de variáveis que não podem ser realisticamente observadas, medidas ou estimadas. Os modelos dão uma idéia dos fatores que estão em jogo quando o tomador de decisões formula doutrinas, e pode entender que o tomador de decisões tem uma compreensão das trocas (trade-offs) envolvidas, mas na ausência da informação sobre as magnitudes destas trocas - e a literatura não dá nenhum sentido destas magnitudes - o tomador de decisões é abandonado com pouca orientação." cf. POSNER, Eric (2008)

${ }^{12}$ Acerca da tertúlia, vide DWORKIN (1980). Vide também a resposta de POSNER (1985) .
}

Revista do Direito da UNISC, Santa Cruz do Sul, v.2, n. 46, p. 03-33, maio - ago. 2015. 
sentido de que "parte substancial do conceito de justiça" pode ser entendida mediante critérios econômicos de eficiência.

Além disso, inevitável a disputa ideológica quando o assunto é $L \& E$. Ronald Coase, Richard Posner e Gary Becker são nomes diretamente ligados à Universidade de Chicago. É notório como o "vírus do L\&E" (WALLER, 2009) se expandiu quando Milton Friedman, Friedrich Hayek, Alan Greenspan e outros defensores do livre mercado forjaram a política econômica neoliberal dos anos 80 nos E.U.A e em vários países da Europa, Ásia e América Latina. Quando muito, o caminho do $L \& E$ tem sido traçado por vias inconscientes de sua falta de neutralidade, já que em grande parte do movimento se notam tendências extremamente criticadas como ideologia justificadora do lucro, do livre-mercado, alinhada ao preceito de Estado mínimo. ${ }^{13}$

Além da resistência ao modelo L\&E nos EUA, suas tendências pautadas por uma epistemologia representativa-objetivista do mundo tem sido vistas com ressalvas também nas instâncias decisórias da União Européia, ao menos em matéria de direito concorrencial (WALLER, 2009), cujo paradigma universalista e centralizador não tem sido adotado. ${ }^{14}$

Seus resultados, apesar de alinhados às heranças do realismo sociológico dos EUA (como dissemos acima), apresentam traços paradoxalmente positivistaslegalistas na medida em que poucas pesquisas são feitas com auxílio do método sociológico. Nesse sentido é a crítica de outras linhas de análise, a exemplo do sociólogo do direito Lawrence Friedman (2011, P. 490), falando dos EUA:

o L\&E não me parece fazer um bom trabalho na explicação das mudanças nos gostos e costumes legais (...) - por que o divórcio consensual varreu 0 país após 1970/71?, por que os índices de crimes crescem e caem?, por que as leis de drogas são aprovadas e quando?, e por qual razão há uma paixão repentina por leis de preservação histórica? Por outro lado, uma respeitável literatura em sociologia do direito e história sócio-jurídica tentam

\footnotetext{
${ }^{13}$ Por vezes manifesto de forma indubitável: "A partir da prova formal relativa à instabilidade das soluções obtidas por meio das regras majoritárias proporcionada pelo teorema da impossibilidade geral de Arrow, os teóricos da Economia Constitucional/Public Choice estendem as conseqüências desse teorema apontando como as decisões políticas sob maioria impactam negativamente na atividade fiscal do Estado levando o setor público a expandir-se para além dos limites fixados constitucionalmente para ele e drenando recursos do setor privado. As soluções propostas para esse inchaço estatal devem estar previstas e figurar na própria Constituição por meio da limitação e definição exógena do conjunto oportunidade referente às decisões tomadas sob maioria". (LEISTER, /2013).

${ }^{14}$ Conforme abordagem de José Reinaldo de Lima Lopes, na verdade a proposta do raciocínio do L\&E capta apenas parte da racionalidade que a economia pode fornecer à apreciação do direito, pondo em xeque exatamente essa noção de centralidade das decisões.( LOPES ,2005)
}

Revista do Direito da UNISC, Santa Cruz do Sul, v.2, n. 46, p. 03-33, maio - ago. 2015. 
dar respostas para cada uma dessas questões. ${ }^{15}$

Talvez por isso alguns avanços se podem notar em continuadores do movimento ao amenizar a tendência abstrata, abrindo ao pesquisador do L\&E perguntas que vão além da superfície da maximização econômica:

Um pessoa roubará ou dirigirá seu carro sem cuidados, matará ou mentirá a menos que o estado crie uma sanção legal contra o roubo, a negligência, o homicídio ou a fraude. Essa descrição do mundo é parcialmente verdadeira, mas majoritariamente falsa. A maioria das pessoas, na maioria das ocasiões, refreiam comportamentos anti-sociais mesmo quando o direito está ausente ou não tem força. Elas se ajustam às normas sociais. A questão que resta sem resposta pelo $L \& E$ é por que isso ocorre. O direito sempre é imposto em face de uma rede de relações não legais - reguladas por fofocas, reprovações, ostracismo e violência - as quais produzem um importante bem coletivo. O sistema de cooperações não-jurídicas é sempre por vezes superior e por vezes inferior às soluções jurídicas, e as intervenções do direito vão refrear ou reforçar essas normas não-jurídicas das maneiras mais complexas. (POSNER, 2002, p. 4)

Outro paradoxo evidente é que a redução dos custos de transação, seja do ponto de vista descritivo-comportamental, seja do ponto de vista jurídico-normativo, não coincide em nada com o aumento brutal dos custos político-jurídicos com os grupos de pressão ou lobbies, que se tornaram custos de transação indispensáveis e insuportáveis na selva competitiva do "supercapitalismo norte-americano". ${ }^{16}$ Segundo Robert Reich (2008), nos anos 90 e 2000, o índice Dow Jones, que mede o movimento de capitais e investimentos dos E.U.A., cresceu astronomicamente inclusive imediatamente após aumentos de impostos dos governos Bush e Clinton. Além disso, os custos de transação com atividades de lobby cresceu de cerca de duzentos milhões de dólares em 1987 para mais de dois bilhões de dólares em 2005.(REICH, 2008, p. 137). Essa característica da economia norte-americana mostra, aliás, que as dependências entre "o mercado" e o Estado são intestinas, revelando uma estrutura que se atrofiou e explodiu os custos de transação exatamente por causa das políticas neoliberais de redução do papel do Estado (!).

A pesquisa que comumente se realiza a título de $L \& E$ não consegue perceber

\footnotetext{
${ }^{15}$ Diz ainda o autor (2011, p.489) sobre o L\&E: "If this approach seems exaggerated, or unrealistic, just think of the daily behavior of most people, ordinary people, in most societies, most days of their lives. People get up in the morning, they dress, they eat, they interact with each other, with their families, with children or parents, they work, they play, they make love. Most of what they do, say, and think during the day has little or nothing to do with "contractual" behavior, or of "maximizing" in any reasonable or realistic sense. Most of it follows well-worn patterns. Most of it is unthinking, habitual, responsive to hidden and unconscious cues. I am, of course, talking about people, not business firms competing in the market, or stock exchanges and the like".

16 A referência é ao termo "supercapitalismo" de Reich (2008).
}

Revista do Direito da UNISC, Santa Cruz do Sul, v.2, n. 46, p. 03-33, maio - ago. 2015. 
esse movimento irracional e incongruente do discurso neoliberal. Antes mesmo das crises financeiras por excessos liberais (a bolha dos negócios de internet, em 2000, e a bolha dos derivativos sub-prime, em 2008) a presença cada vez maior do Estado e das agências políticas lato sensu na condução da economia dos EUA é questão que merece atenção, revelando exatamente o contrário do que se imagina em Wall Street.

Por razões como essas, críticas mais contundentes ainda estão por serem desenvolvidas, compondo um verdadeiro programa de pesquisa em análise econômica do direito em termos realistas, que podemos sumariar em três grandes linhas de confronto ao paradigma $L \& E$, para revisão de seus postulados e melhor compreensão das finalidades de uma pesquisa brasileira (ou local) a respeito do tema:

a) Críticas dialético-realistas em termos hegeliano-marxistas.

b) Relevo das especificidades histórico-concretas e o conceito de fontes materiais.

c) A necessidade de um nuevo constitucionalismo latino americano.

\section{CRÍTICAS DIALÉTICA-RELAISTA AO L\&E}

A primeira distinção essencial de qualquer epistemologia dialética fundada em Georg F.W. Hegel é a superação da dicotomia razão vs. história. A história é um percurso espiritual da humanidade para Hegel, manifestação de uma crescente racionalidade que vai se efetivando no mundo. Para citar importante exemplo de sua filosofia da história, em sua época, Hegel acreditava que a marcha estava já avançada e o Estado moderno, inspirado pelos ideais racionalistas do iluminismo, era uma manifestação dessa racionalidade.

Em segundo lugar, uma distinção muito ligada à primeira: se a racionalidade humana é histórica, o processo de conhecimento não pode ser contemplativo, mas ativo. Daí que Hegel se vê obrigado a reformular completamente a lógica tradicional, baseada nos princípios de identidade, não-contradição, terceiro-excluído, substância, regularidade (leis) etc. Se a lógica clássica foi erigida em estreita relação com a ontologia de Parmênides de Eleia, a nova lógica teria igual missão, mas agora 
em estreita relação com a ontologia de Heráclito de Efeso: só se capta a razão na história se formos capazes de perceber as coisas no mundo em permanente transformação.

Os conceitos da filosofia (e das ciências, portanto) só podem ser compreendidos numa implicação que não é denotativa-representativa do mundo. É ação transformadora do mundo e, portanto, afeita à contradição, pois uma coisa só pode ser compreendida em relação com aquilo que ela "vem a ser", seu devir, outra coisa, portanto, seu "não-ser".

Numa terceira distinção, nessa nova lógica, a lógica dialética, a maior riqueza epistêmica é a permanente relação entre o espírito humano e suas determinantes concretas. Os conceitos não podem ser apenas abstratos, mas enraizados no concreto das singularidades que o manifestam e o transformam pela ação histórica. O mundo, em virtude disso, é uma inundação de contradições, de implicações de forças reais e conceituais, que só o espírito humano muito evoluído poderia decifrar. Eis o papel do espírito absoluto segundo Hegel, a soma de todas as determinantes concretas e abstratas que caminha com a história, depende dos homens, mas não se confunde com eles, depende das dimensões vitais e concretas, mas igualmente não se reduz a elas.

Eis as bases, em poucas linhas, da revolução dialética proposta por Hegel. A ênfase aqui adotada, todavia, não é de matriz hegeliana, exatamente pelas críticas que lhe formulou um de seus maiores intérpretes: Karl Marx. Suas referências a Hegel são textuais, muito embora haja permanente tertúlia sobre as dependências e rupturas entre Marx e Hegel. O trecho que adotamos, no sentido de captar o pensamento marxiano com matriz hegeliana, exatamente porque propõe uma lógica dialética e especialmente porque começa a explorar a tese hegeliana das relações tensas entre espírito (idéia) e matéria (real) é o seguinte, nas palavras de Marx ( 2013, p. 90-91):

Meu método dialético, em seus fundamentos, não é apenas diferente do
método hegeliano, mas exatamente o seu oposto. Para Hegel, o processo
do pensamento, que ele, sob o nome de Idéia, chega mesmo a transformar
em sujeito autônomo, é o demiurgo do processo efetivo, o qual é apenas a
manifestação externa do primeiro. Para mim, ao contrário, o ideal não é
mais que o material, transposto e traduzido na cabeça do homem. (...) A
mistificação que a dialética passa nas mãos de Hegel não impede em
absoluto que ele tenha sido o primeiro a expor, de modo amplo e
consciente, suas formas gerais de movimento. Nele, ela está de cabeça
para baixo. É preciso desvirá-la, a fim de descobrir o cerne racional dentro v.2, n. 46, p. 03-33, maio - ago. 2015. 
do invólucro místico.

Nas poucas linhas desse artigo, não seria possível derivar mais consequências e atualizar as discussões, restando lembrar que os estudos da dialética marxista só podem prosperar se for muito bem compreendido o que significa "virar a dialética de cabeça para baixo", descrito pelo verbo alemão "umstülpen" que melhor seria traduzido por "virar do avesso", tal como quando se inverte uma luva pelo seu avesso ou se arregaçam as mangas de uma camisa. Essa é uma questão fundamental, que exige atenção na medida em que é a "prova de realidade" da epistemologia dialético-realista.

Como é amplamente sabido, Marx realizou uma fundação de sua lógica dialética "invertida" exatamente na contradição entre capital e trabalho. Essa prova é uma prova no sentido dialético, não podendo jamais ser comprovada no sentido clássico positivista do termo. Mas ela tem sentido inequívoco na atualidade ao mostrar a deterioração crescente das relações de emprego em virtude da negação que o capital the proporciona ${ }^{17}$, seja pela expulsão da mão-de-obra produtiva pelo incremento da maquinaria, seja pelos a autonomia do capital financeiro que aparentemente se descola de qualquer base produtiva conforme o livro III d'O Capital. Esse movimento tardio do capitalismo foi previsto por Marx em sentido problemático, dialético, mas estruturado em observações das tendências do capitalismo industrial de seu tempo. Segundo ele, a fundação dialética implica que, ao contrário de Hegel, a contradição entre capital e trabalho não se resolve pela razão, nem pela superação da contradição de um conceito-real pelo outro conceitoreal. Isso porque só o capital pode, na realidade, negar-se a si mesmo, tornar-se trabalho para superar-se enquanto totalidade. ${ }^{18}$ A análise é de Jorge Grespan (2003, p. 32):

O trabalho não tem a capacidade de reduzir o capital a seu momento para então, dessa negação, superar-se enquanto totalidade e isso é uma impossibilidade derivada de uma lógica do concreto, diferentemente do que se poderia conceber formalmente, hegelianamente, numa articulação conceitual entre capital e trabalho, superada ao final pelo espírito.

É aqui o ponto de partida para uma análise econômica do direito que vai se

\footnotetext{
${ }^{17}$ Para tanto, vide Antunes (2005).

${ }^{18}$ Para mais detalhes dessa questão, vide Pontes (2011).
}

Revista do Direito da UNISC, Santa Cruz do Sul, v.2, n. 46, p. 03-33, maio - ago. 2015. 
destrinchar em preciosos elementos epistêmicos para a reflexão (e ação) sobre o mundo em que vivemos: a percepção do movimento, da história, das contradições reais da vida material e econômica, a relação desses elementos reais com a consciência espiritual, a cultura, os valores, a ética e o direito. Enfim, uma das propostas mais intrigantes do que podemos chamar de filosofia marxiana deriva dessas inovações epistêmicas, com implicações essenciais para o estudo atual do direito: as relações entre economia/estrutura (produção material da vida) e direito/superestrutura (relações sociais). Como seria uma possível análise econômica do direito tendo como ponto de partida o seguinte texto de Marx?:

A produção de idéias, de representações e da consciência está em primeiro lugar direta e intimamente ligada à atividade material e ao comércio material dos homens; é a linguagem da vida real. As representações, o pensamento, o comércio intelectual dos homens surgem aqui como emanação direta do seu comportamento material. 0 mesmo acontece com a produção intelectual quando esta se apresenta na linguagem das leis, política, moral, religião, metafísica, etc., de um povo. São os homens que produzem as suas representações, as suas idéias, etc., mas os homens reais, atuantes e tais como foram condicionados por um determinado desenvolvimento das suas forças produtivas e do modo de relações que lhe corresponde, incluindo até as formas mais amplas que estas possam tomar. A consciência nunca pode ser mais do que 0 Ser consciente e o Ser dos homens é o seu processo da vida real. E se em toda a ideologia os homens e as suas relações nos surgem invertidos, tal como acontece numa câmera obscura, isto é apenas o resultado do seu processo de vida histórico, do mesmo modo que a imagem invertida dos objetos que se forma na retina é uma conseqüência do seu processo de vida diretamente físico. (MARXS; ENGELS, 1984, p. 22)

O capitalismo contemporâneo, em suas várias descrições (pósindustrial, capitalismo de estado, liberal, "supercapitalismo" etc.), possui formas econômicas com evidentes relações com as formas jurídicas que compõem suas estruturas reprodutivas. As várias facetas do jurídico devem encarar, portanto, uma confrontação das contradições entre forma e matéria, no dizer de Alaôr Caffé Alves ( 2010, p. 16)

A forma ingressa como organizadora do conteúdo, sem a qual o próprio conteúdo não se realiza. É precisamente essa questão que lança grande dúvida a respeito das relações entre estrutura e superestrutura, especialmente no que respeita às ligações entre as relações de produção econômica e o direito. Não há relações capitalistas de produção se não houver o direito correspondente; logo, as relações produtivas (estrutura) dependem da superestrutura, dependem das relações normativas. Sem estas, aquelas relações produtivas não existem. Assim, há um caráter sistêmico da realidade em que uma parte depende de outra. Entretanto, a concessão, no máximo, é a de que ambas são necessárias para a existência do processo de produção burguesa, e isso significa que não se pode dar prioridade à estrutura em detrimento da igual necessidade superestrutural do direito. (...) Isto está correto na medida em que não de pode conceber um conteúdo sem forme e vice-versa

Revista do Direito da UNISC, Santa Cruz do Sul, v.2, n. 46, p. 03-33, maio - ago. 2015. 
Sob um ponto de vista da análise econômica do direito, podemos argumentar que os excessos liberais do $L \& E$, notadamente no direito dos contratos, como vimos, realizam uma performance atual e inconsciente da atualidade de um dos mais importantes juristas ligados ao pensamento de Marx: Eugeny Pachukanis. Do contrário, não haveria análise de qualquer relação jurídica em termos monetários, com vistas à maximização dos lucros, segundo uma racionalidade da equivalência de mercadorias:

\begin{abstract}
A sociedade capitalista é antes de tudo uma sociedade de proprietários de mercadorias. Isto significa que as relações sociais dos homens no processo de produção possuem uma forma coisificada nos produtos do trabalho que se apresentam, uns em relação aos outros, como valores. A mercadoria é um objeto no qual a diversidade concreta das propriedades úteis torna-se, simplesmente, invólucro coisificado da propriedade abstrata do valor, que se exprime como capacidade de ser trocada em uma proporção determinada em relação a outras mercadorias. (PACHUKANIS, 1989, p. 84)
\end{abstract}

É de Pachukanis (1989) a captação da forma jurídica em estreita relação com a forma mercadoria, usando categorias da dialética concreta para pensar os limites do direito na sociedade capitalista. Inúmeros e preciosos trabalhos desenvolvem o pensamento deste autor. ${ }^{19}$ Investigações como essas, todavia, têm de ter em mente uma contribuição extraordinária da dialética entre forma jurídica e matéria econômica sob o ponto de vista concreto. Sem ela, qualquer análise da economia e do direito, nos dias de hoje, corre sérios riscos metafísicos:

Ao não considerar essa reciprocidade dinâmica e conflitiva entre matéria e
forma, os teóricos economistas do sistema hegemônico do capital acabam
por tratar apenas um lado da questão (geralmente apenas o avanço
tecnológico das forças produtivas, o conteúdo) sem atender de modo
inovador às necessidades de alteração profunda do lado da organização do
sistema, do lado da forma. Outro exemplo: o acentuado desenvolvimento da
produção industrial em massa do atual sistema capitalista (conteúdo),
fazendo grande pressão sobre a disponibilidade e a qualidade dos recursos
naturais do planeta, condiciona a necessidade de reorganizar a ordem
jurídica (forma) para dar conta dos problemas ambientais e ecológicos.
Surge, então, o direito do meio ambiente ou direito ecológico. (ALVES,2010,
p. 65).

Além disso, a aplicação da lógica dialética força o estudioso do capitalismo contemporâneo a rever suas categorias de representação do mundo, superando a simples analiticidade teórica, o individualismo metodológico, rumo a uma concepção que supere o paradigma da filosofia da consciência que de que ainda está

19 Vide CASALINO ( 2011) e KASHIURA (2009) e AKAMINE JUNIOR (2002) .

Revista do Direito da UNISC, Santa Cruz do Sul, v.2, n. 46, p. 03-33, maio - ago. 2015. 
impregnada a imensa maioria dos estudos do L\&E. Nesse sentido, é preciso compreender que a lógica marxista é uma lógica da práxis, a única apta a compreender e agir no mundo diante das contradições que o sistema capitalista crescentemente revela:

Efetivamente, as contradições fundamentais em que a sociedade capitalista se debate em nossa época chegaram a tal agravamento que os homens apenas podem resolvê-las e assegurar, assim, um porvir verdadeiramente humano atuando em um sentido criador, isto é, revolucionário. Hoje mais do que nunca, os homens precisam esclarecer teoricamente sua prática social e regular conscientemente suas ações como sujeitos da história. E para que essas ações se revistam de um caráter criador, necessitam também (...) de uma elevada consciência das possibilidades objetivas e subjetivas do homem como ser prático, ou seja, uma verdadeira consciência da práxis. (VÁLQUEZ, 2007, p. 57)

\section{RELEVO DAS ESPECIFICIDADES HISTÓRICO-CONCRETAS E O CONCEITO DE FONTES MATERIAIS}

Segundo a abordagem de J.R. Lima Lopes, a proposta do raciocínio do $L \& E$ capta apenas parte da racionalidade que a economia pode fornecer à análise do direito. Essa escola manifesta uma tendência de isolar comportamentos "eficazes" em relação a padrões do direito e da moralidade que não atendem à racionalidade instrumental proposta. Além disso, o $L \& E$ analisa apenas comportamentos atomizados, relativos ao conceito comutativo de justiça, enquanto as decisões importantes de planejamento econômico e de políticas públicas de justiça social ficam de fora dessa análise em grande medida.

Daí que um programa de pesquisa sério para as relações entre direito e economia deve fazer um movimento de regresso ao real no sentido de analisar não apenas as fontes formais do fenômeno jurídico, mas suas fontes materiais. ${ }^{20}$ Assim é que dos estudos da dialética histórico-concreta extraem-se outras categorias indispensáveis à análise, a exemplo da universalidade abstrata e universalidade concreta.

Sob essas categorias, o discurso econômico predominante, especialmente em virtude do capitalismo avançado e globalizado, se situa em torno das universalidades abstratas, como se as categorias mentais pudessem ajustar o mundo aos seus preceitos, com pouca ou nenhuma preocupação histórica. Essa tendência cartesiana e iluminista é clássica e precisa ser rompida em virtude do alto

\footnotetext{
${ }^{20}$ De maneira similar ao conceito de fontes materiais do direito apresentado por Mialle (1979).
}

Revista do Direito da UNISC, Santa Cruz do Sul, v.2, n. 46, p. 03-33, maio - ago. 2015. 
grau de abstração que categorias enraizadas em países "desenvolvidos" tendem a ser importadas para outros países com diferenças históricas e econômicas brutais, sem maiores considerações. ${ }^{21}$ É o que ocorre especialmente com a doutrina brasileira que importou o L\&E em descuidada sujeição à "violência simbólica" (BOURDIEU e PASSERON, 1975) dos E.U.A nos estágios de desenvolvimento econômico, tecnológico, cultural e acadêmico.

\begin{abstract}
A universalidade abstrata [...] propicia o não reconhecimento do sujeito concreto, sujeito real, no processo do conhecimento, posto que a dimensão universal é desligada da história na qual ela se realiza, do processo que a torna possível [...] do próprio ser humano como ser de necessidades, de carne e osso.

O universal concreto, entretanto, de modo oposto, é a representação de uma generalidade determinada, expressa na síntese das particularidades de algo que se apresenta exatamente como unidade do diverso. [...] Aí temos o universal concreto, 0 universal que exprime a unidade do gênero na diversidade das espécies, no interior de um processo dialético.

[Um] exemplo é a utilização da palavra "democracia" como rótulo genérico para todo e qualquer regime de governo[...] por meio do voto. [...]. Se, entretanto, considerarmos a particularidade, entre muitas possíveis formas de democracia, poderemos compreender a realidade política de um regime de governo específico sem cairmos nas malhas da fraude ideológica. Para isso, a particularidade deve ser mencionada através de uma qualificação determinada (adjetivada), descendo ao nível da história dos regimes políticos reais. [...] As democracias particulares não são meros acidentes da democracia universal (que não existe como tal no mundo); elas perfazem a realidade histórica das democracias cujas diferenças são extremamente significativas para a existência política e social de cada povo.( ALVEZ, 2012, p. $70-92$ )
\end{abstract}

Sob esse ponto de vista, agora, cada categoria da teoria do direito, da teoria do estado e da economia, para dizer o mínimo, pode ter luzes em termos muito mais realistas, na medida em que de nada adianta falar de conceitos se as realidades caminham em sentido diverso do que dizem as teorias. Se houver algum poder de alteração da estrutura social econômica pelo direito, isso só poderá ser pensado à luz dos universais concretos:

Sob esse ponto de vista histórico, outras peculiaridades brasileiras apontam para uma compreensão bem mais concreta do movimento formador dos conceitos jurídicos, com evidentes consequências no campo decisório e jurídico-hermenêutico. Segundo o $L \& E$, como vimos, o surgimento de novos conceitos como liability rules deveu-se à crescente necessidade de eficiência, sempre pautada pela redução dos

\footnotetext{
${ }^{21}$ Aqui também se encontram ecos no sentido das investigações de G.Becker e R.Posner. Rachel Sztajn cita o exemplo segundo o qual as regras relativas à adoção e guarda de crianças seriam como preços a serem pagos por gratidão, afeto. (ZYLBERSZTAJN, 2005).
}

Revista do Direito da UNISC, Santa Cruz do Sul, v.2, n. 46, p. 03-33, maio - ago. 2015. 
custos dos negócios à Coase. Aqui, a explicação é outra e bem mais completa:

O direito de propriedade, por exemplo, não é idêntico a si mesmo, ele pressupõe uma unidade da diversidade, tem uma história, ele se transforma com o desenvolvimento das forças produtivas da sociedade. [...] Essa transformação não decorre da evolução do conceito de propriedade na cabeça dos homens, à moda idealista, mas é a expressão das novas exigências do mundo material dos homens, de suas relações sociais específicas e de suas condições dinâmicas de existência e subsistência.( ALVEZ, 2012, p. 38)

Analisar as alterações do direito de propriedade aplicando a categoria do universal concreto implica levar a sério as peculiaridades da história política brasileira, da história da cultura brasileira, da história da economia brasileira, para pensar a história da propriedade no direito brasileiro e dos limites do direito em relação às sobre-determinações recíprocas dessa peça fundamental jurídica em relação às estruturas econômicas. ${ }^{22}$

Um exemplo de análise econômica do direito de propriedade levada a sério, nesse sentido foi feita por Tarso de Melo, em termos claramente definidos pela filosofia da práxis:

A crítica do capitalismo e, no nosso caso, das ilusões jurídicas que o fortalecem é indispensável. Se o sistema tem limites e possibilidades, eles devem ser forçados, como o fazem os militantes da luta pela terra; enquanto aqueles limites resistirem, que ao menos as possibilidades do sistema dêem uma vida mais digna ao maior número de pessoas possível. [...] A luta política restitui, em certos casos, os sem-terra à condição de sujeitos concretos, de carne e osso, não mais como sujeitos de direito considerados em igualdade de condições com o latifundiário. E este é um viés importantíssimo da luta pela terra, porque força a ruptura do véu de neutralidade que encobre a atuação judiciária. (MELLO, 2009, p. 12-13)

Ao analisarmos as políticas públicas e os planos econômicos e jurídicos nacionais dos últimos 80 anos e seus efeitos, os conceitos da responsabilidade civil objetiva e a flexibilidade da legislação na regulação econômica são mais bem compreendidos. O diagnóstico é de Lopes (1990, p. 184, tradução nossa):

Surgiu o consenso de que a legislação econômica relativa ao desenvolvimento e ao planejamento poderia ser alterada e revista sem garantir aos cidadãos, em princípio, o direito de indenização pela Administração (...). As leis sobre regulação econômica foram consideradas naturalmente "flexíveis", ou seja, elas vinculam, mas dentro dos limites de "possibilidade econômica" (...). Assim, a doutrina da responsabilidade civil teve de ser revista para acomodar a responsabilidade do Estado no caso

\footnotetext{
${ }^{22}$ Ou seja, no mínimo com aproximações a Raimundo Faoro, Caio Prado Jr., Gilberto Freyre, Sergio Buarque de Holanda e Boris Fausto.
}

Revista do Direito da UNISC, Santa Cruz do Sul, v.2, n. 46, p. 03-33, maio - ago. 2015. 
das políticas de desenvolvimento ou planejamento econômico. A ação do governo nestas áreas não deve ser rigorosamente comparada à quebra de contrato, de promessa ou casos tradicionais de dano em geral.

Em direito econômico e da concorrência, em que a relação entre direito e economia é mais ainda evidente, é possível ver esforços aqui e ali no sentido de captar o movimento histórico local para, no mínimo, uma melhor compreensão do fenômeno jurídico-econômico brasileiro. ${ }^{23}$ A busca da eficiência permitiria a aproximação entre direito e economia no que tange aos conceitos mais caros da teoria geral do direito, a exemplo das relações entre validade e eficácia. A aprovação do Código de Defesa do Consumidor em 1990 é um exemplo claro. Aqui vemos uma substancial alteração da relação entre os órgãos governamentais e as agências de controle das políticas relativas à garantia dos direitos difusos, coletivos e contra a ordem econômica, especialmente com a criação do "compromisso de ajustamento de conduta" pela inserção de um parágrafo no artigo 5o da Lei da Ação Civil Pública (lei $n^{\circ}$ 7.347, de 24 de julho de 1985). ${ }^{24}$

O relato do secretário de meio-ambiente do governo do Estado de São Paulo, na gestão de 1991/2 é um exemplo cabal da necessidade de rever os conceitos jurídicos pela base material-econômica a fim de garantir a eficácia da legislação ambiental recente. Em defesa dos interesses coletivos e difusos, o governo passou a aplicar sistematicamente multas às indústrias que despejavam seus efluentes nos rios que cortam a cidade de São Paulo. A pressão das indústrias foi imensa no sentido de que a simples aplicação da lei sem consideração do histórico da produção industrial paulista (que sempre teve a tolerância governamental com a poluição inerente à atividade) seria uma tragédia econômico-social. A legislação, naquele contexto, foi alterada para que houvesse transições negociadas em situações que o direito e a economia não podiam andar separadamente. ${ }^{25}$

\footnotetext{
${ }^{23}$ Nesse sentido, destacam-se Bercovicil (2012) e Coutinho ( 2013) .

${ }^{24}$ Ainda Lopes (1990, p. 188): "Coisas parecidas podem ser encontradas na lei de defesa da concorrência, no caso do "compromisso de desempenho", no art. 58. Mesmo após uma decisão já tomada, a autoridade administrativa acompanhará as atividades das partes interessadas para ver se os resultados estão ou não sendo alcançados" (p.188). (tradução nossa).

25 "Nesse período, o Termo de Ajustamento de Conduta era feito, sob o controle do Ministério Público, em razão da Ação Civil Pública, após a situação de dano causado ter sido aferida e instaurado o respectivo remédio processual. Esse remédio era aplicado a posteriori. Diante do clamor dos empresários, da necessidade de resguardar a legalidade da ação administrativa, bem assim da efetividade do controle ambiental, considerei a possibilidade de negociar com os empresários a realização de condutas programadas para a implantação, em tempo aprazado, de mecanismos, instalações, equipamentos, construções e ações preventivas e recuperativas, objetivando o alcance do equilíbrio ambiental, dentro de um cronograma viável e um plano de investimento aceitável, devidamente acertado com eles, mediante um termo de conduta responsável. Seria a primeira
}

Revista do Direito da UNISC, Santa Cruz do Sul, v.2, n. 46, p. 03-33, maio - ago. 2015. 
O destaque para essa análise inédita de Alvez (2013) vai para o seguinte trecho:

\begin{abstract}
Esse foi mais um lance da nova realidade jurídica, traspassando o mero positivismo dogmático, configurando a necessidade diuturna de se considerar a especificidade das situações que, dificilmente, se enquadram nos limites precisos e formais da lei apriorística, abstrata e geral. Por isso, os parlamentos perdem sua importância relativa quando, inevitavelmente, nos dias de complexidade crescente das forças produtivas de hoje, a normatividade tem que descer aos meandros das circunstâncias fáticas e sociais, ad hoc, contrariando as velhas dinâmicas do empreendedorismo liberal, que não tinham que levar em conta os grandes e concretos contextos sociais, geográficos, econômico, ambientais e culturais que hoje demandam atenção substancial e inelidível dos setores público e privado. Por isso, os conselhos vinculados aos mais variados temas, com membros representantes de todos os setores, passam a normatizar com grande desenvoltura e pertinência, para os casos particulares e para as situações singulares. É precisamente o caso da exigência dos "estudos prévios de impactos ambientais" (EPIA-RIMA) para os empreendimentos potencialmente im pactantes e poluidores. Os tempos são efetivamente outros!
\end{abstract}

\title{
CONSIDERAÇÕES FINAIS
}

Em virtude do exposto, a perfeita compreensão histórica do desenvolvimento econômico brasileiro e das consequentes análises jurídicas da economia, ou viceversa, só é possível com o uso de uma lógica dialético-realista da formação dos conceitos universais concretos, exigindo, portanto, uma análise econômica do direito brasileiro, assim como deveria ocorrer em todo país. Todavia, em termos dialéticos, entre a universalidade abstrata dos elementos globalizados da economia e suas manifestações concretas brasileiras existem gradações intermediárias o produto das tensões de idéias universais com manifestações concretas diversas, mas similares.

A consideração da história real do Brasil, nesse sentido, se torna elemento indispensável para um sucesso de um entrelaçamento entre o conceito de direito e

experiência nesse sentido, no âmbito da Administração Pública. De certo modo, deveria romper com a aplicação tradicional da lei, negociando os seus termos! Foi o que efetivamente ocorreu, dando viabilidade às atividades industriais, dentro de um esquema razoável que não significasse o sacrifício do meio-ambiente, das atividades econômicas, da situação social e da exigibilidade legal."( ALVES, 2013).

Revista do Direito da UNISC, Santa Cruz do Sul, v.2, n. 46, p. 03-33, maio - ago. 2015. 
as tendências econômicas. A tendência dos historiadores e economistas de captar um esforço de formação de um Estado de bem estar social no Brasil desde a era Vargas mostra um desastroso insucesso nas políticas de planejamento, desenvolvimento e formação de agências de fomento e controle de políticas públicas na execução das medidas propostas. A dissociação entre história e conceitos se deveu notoriamente à importação de modelos primeiro dos EUA, que nunca teve uma proposta político-constitucional de Welfare State, segundo da Europa, que se por um lado tinha um modelo claro de Welfare State, por outro lado possuía uma estrutura decisória nos âmbitos jurídico e administrativo que não serviria às políticas públicas brasileiras. ${ }^{26}$

Uma lavra de estudos regionais ou locais, no sentido universal concreto, pode conquistar importantíssimos aprimoramentos em torno do próprio conceito de Estado, em busca de limites mais delineados de um conceito viável de Estado desenvolvimentista de bem estar social, experiência típica de alguns países latinoamericanos com alguns traços históricos comuns. ${ }^{27}$

É preciso associar a concepção histórica de um Estado desenvolvimentista de bem estar social e as teorias do direito constitucional, numa clara reação em relação ao pensamento pós-positivista. O surgimento de vozes em termos de novos preceitos da teoria político-constitucional soando num mesmo tom latino-americano permitem ver aspectos importantes das peculiaridades históricas. É o que se propõe nos últimos anos como movimento do nuevo-constitucionalismo-latino-americano.

A primeira virtude notória desse movimento é sua afirmação em termos castellanos ou brasileiros, numa clara oposição política à já referida "violência simbólica" do pensamento europeu e norte-americano que se torna evidentemente abstrato quando importado sem o atenção ao concreto.

\footnotetext{
${ }^{26}$ LOPES, José Reinaldo de Lima. The traditional....cit. p.184.

${ }^{27}$ Sobre o Welfare State, em perspectiva histórica, segundo entendemos numa análise próxima de um universal concreto, interessante notar os estudos sobre um "estado de bem estar social especificamente latino-americano" (Latin American Developmental Welfare State), de Manuel Riesco: "O curso da transição [de um estado de bem estar social latino-americano] parece ser o processo geral sublinhando e determinando o principal fenômeno sócio-econômico da região, incluindo a suas políticas sociais ao longo do século XX - e os graus relativos de avanço que claramente explicam muitas das suas diferenças. Por outro lado, os vários caminhos para a modernidade, profundamente enraizados em séculos de rotas históricas extremamente diversificadas entre os distintos países e regiões, parecem ter demarcado muitas características em cada um deles - e também exercido uma influência decisiva na forma e no grau relativo de avanço em seus processos de transição. Para enfatizar a relevância metodológica deste aspecto muitas vezes ignorado, os países estudados neste livro foram agrupados de acordo com estes padrões de desenvolvimento histórico(...). No entanto, como enfatizado pelas ciências sociais, são os eventos e instituições, atores sociais e políticos e as estratégias que adotam, que, finalmente, concentram neles os vetores resultantes de tais forças econômicas, sociais e históricas gerais e particulares". (RIESCO, 2013, p. 38, tradução nossa).
}

Revista do Direito da UNISC, Santa Cruz do Sul, v.2, n. 46, p. 03-33, maio - ago. 2015. 
O que se convencionou chamar de "neo-constitucionalismo", nesse sentido, deve ser superado na medida em que suas categorias ainda se apresentam em termos universais (notadamente europeus), insuficientes para uma pauta de conquistas locais no inevitável confronto com os movimentos globais do capital e do direito a eles associados. Só faz sentido falar de direito constitucional e das lutas populares para sua concretização nas experiências do Brasil, ou naquelas da Argentina, ou do Equador, do Paraguai, da Colômbia diante de suas experiências, ainda que se encontrem traços comuns que reforçam seu aspecto político.

Por fim, para as pesquisas futuras das relações entre direito e economia, é indispensável pensar as categorias da filosofia da práxis com a coragem que merecem. É certo que um nuevo-constitucionalismo só fará sentido se os povos intensificarem o grau de consciência pela ação, transformação e conservando suas culturas em resistência à pressão pela institucionalização de falácias jurídicas massacrantes do capitalismo globalizado, como lamentavelmente tem ocorrido na história recente de nossas experiências regionais. ${ }^{28}$ Essa coragem, por óbvio, não pode se alienar da realidade universal concreta do capitalismo contemporâneo, mas supõe tomada de consciência dos movimentos regionais para um confronto, do qual não sairá emancipação alguma nem pela exclusividade do discurso, nem pela via única da política ou da afirmação retórica da positivação das "garantias" constitucionais:

O capital tem um sistema de metabolismo e de controle social
essencialmente extra-parlamentar. Desse modo, qualquer tentativa de
superar este sistema de metabolismo social que se atenha à esfera
institucional e parlamentar, estará impossibilitada de derrotá-lo. O maior
mérito destes novos movimentos sociais de esquerda aflora na centralidade
que conferem às lutas sociais. O desafio maior do mundo do trabalho e dos
movimentos sociais de esquerda é criar e inventar novas formas de atuação
autônomas, capazes de articular e dar centralidade às ações de classe. O
fim da separação, introduzida pelo capital, entre ação econômica, realizada
pelos sindicatos, e ação político-parlamentar, realizada pelos partidos, é
absolutamente imperiosa. A luta contra o domínio do capital deve articular
luta social e luta política num complexo indissociável. (ANTUNES, 2005 p.
226-227)

Esse projeto só faz sentido à luz das categorias dialético-realistas, restando o convite a seus os pesquisadores das diversas áreas para que ampliem seu potencial de explicação e transformação do mundo diante de seus olhos, a começar pelo seu bairro.

\footnotetext{
${ }^{28}$ A exemplo dos "Chicago boys" na lamentável experiência econômica, política e jurídica do Chile no período Pinochet.
}

Revista do Direito da UNISC, Santa Cruz do Sul, v.2, n. 46, p. 03-33, maio - ago. 2015. 


\section{REFERÊNCIAS}

AKAMINE JR., Oswaldo. Considerações sobre o Direito como instrumento ideológico. Uma perspectiva da linguagem. 2002. Dissertação (mestrado em Direito) - Faculdade de Direito da Universidade de São Paulo. 2002.

ALVES, Alaôr Caffé. Dialética e Direito: linguagem, sentido e realidade. SP: Manole, 2010.

29 abr. 2013, São Paulo [para] PONTES, José Antonio S. doc.digital. 2p.

ALVES, Maria V. Neoconstitucionalismo e novo constitucionalismo latino-americano: características e distinções. Revista da Seção Judiciária do Rio de Janeiro. 2012 Aug 28;19(34). Acesso em: 20/04/2013. Disponível em:

http://www4.jfri.jus.br/seer/index.php/revista sjir/article/viewFile/363/289

ANTUNES, Ricardo. Os sentidos do trabalho: Ensaio sobre a afirmação e a negação do trabalho. São Paulo : Boitempo. 2005.

BALDI, César Augusto. Do constitucionalismo moderno ao novo constitucionalismo latinoamericano descolonizador. In: BELLO, Enzo. (org.) Ensaios críticos sobre direitos humanos e constitucionalismo [recurso eletrônico].- Dados eletrônicos. Caxias do Sul, RS: Educs, 2012.

http://www.ucs.br/site/midia/arquivos/Ensaios criticos sobre direitos humanos.pdf

BECKER, Gary S. Essays in the Economics of Crime and Punishment, edited with William M. Landes, Columbia University Press for the National Bureau of Economic Research, 1974.

Chicago Press, 1976.

The Economic Approach to Human Behavior, University of

. The Economics of Discrimination, University of Chicago

Press, 1957;

BERCOVICl, Gilberto. O Direito como Instrumento da Política Econômica. Revista dos Tribunais (São Paulo. Impresso), v. 923, p. 53-62, 2012. Acesso em:

20/04/2013. Disponível em:

http://ojs.unifor.br/index.php/rpen/article/download/2163/1764

BLOCK, Walter E., Market Inalienability Once Again: Reply to Radin (July 19, 2011). Thomas Jefferson Law Review, Vol. 22, 1999. Acesso em 20/04/2013. Disponível em: http://ssrn.com/abstract=1889458

BORGES, Letícia P.C. \& SIMINIONI, Rafael. Decisão jurídica e dilemas póspositivistas da interpretação correta: o substancialismo de Ronald Dworkin e o pragmatismo de Richard Posner. Revista da AJURIS. Porto Alegre. v.38. n.121. p.201-18. mar. 2011.

Revista do Direito da UNISC, Santa Cruz do Sul, v.2, n. 46, p. 03-33, maio - ago. 2015. 
BOURDIEU, Pierre \& PASSERON, Jean Claude, A Reprodução, São Paulo, Francisco Alves, 1975.

CALABRESI, Guido \& MELAMED, Douglas, Property Rules, Liability Rules, and Inalienability: One View of the Cathedral, 85 Harv. L. Rev. 1089 (1972). Acesso em: 20/04/2013. Disponível em:

http://digitalcommons.law.yale.edu/cgi/viewcontent.cgi?article=3043\&context=fss pa pers

CALABRESI, Guido, An Exchange: About Law and Economics: A Letter to Ronald Dworkin (1980). Faculty Scholarship Series. Paper 1994. Disponível em: http://digitalcommons.law.yale.edu/fss papers/1994 Acesso em: 20/04/2013. . Some Thoughts on Risk Distribution and the Law of Torts, 70 Yale L. J. 499 (1961). Disponível em:

http://digitalcommons.law.yale.edu/cgi/viewcontent.cgi?article=3035\&context=fss pa pers Acesso em: 12/04/2013.

CAMPBELL, David. The End of Posnerian Law and Economics. The Modern Law Review, ISSN 0026-7961, 03/2010, Volume 73, Número 2, pp. 305 - 330. Acesso em: 20/04/2013. Disponível em: http://onlinelibrary.wiley.com/doi/10.1111/j.14682230.2010.00796.x/abstract

CASALINO, Vinícius. 0 direito e a mercadoria. para uma critica marxista de Pachukanis. São Paulo: Dobra Editorial, 2011.

Case Spur Industries, Inc. v. Del E. Webb Development Co. Acesso em: 20/04/2013. Disponível em: http://www.casebriefs.com/blog/law/property/propertylaw-keyed-to-dukeminier/judicial-land-use-controls-the-law-of-nuisance/spurindustries-inc-v-del-e-webb-development-co-3/2/

COASE, Ronald. H. The Institutional Structure of Production. Nobel Lecture. The Novel Foundation, 1991.

. O problema do custo social. The Latin American and

Caribbean Journal of Legal Studies. Volume 3, Issue 12008 Article 9, p.36.

Acesso em: 20/04/2013. Disponível em:

http://services.bepress.com/lacils/vol3/iss $1 /$ art9/

COUTINHO, Diogo R. O Direito nas Políticas Públicas. In: MARQUES, Eduardo e FARIA, Carlos Aurélio Pimenta de. (Org.). A Política Pública como Campo

Multidisciplinar. 1ed. São Paulo e Rio de Janeiro: Editora Unesp e Editora Fiocruz, 2013, v. 1, p. 181-200. Acesso em: 20/04/2013. Disponível em:

http://www.cebrap.org.br/v2/files/upload/biblioteca virtual/item 766/14 $0512 \quad 160$ direito nas politicas publicas FINAL.pdf

DOOMEN, Jasper. Rationality in Law and Economics. Economic analysis of law review. 2011;2(2):230-243. Acesso em: 20/04/2013. Disponível em:

http://portalrevistas.ucb.br/index.php/EALR/article/view/2\%20EALR\%20230/2\%20EA LR\%20352\%20-\%20pt

Revista do Direito da UNISC, Santa Cruz do Sul, v.2, n. 46, p. 03-33, maio - ago. 2015. 
DWORKIN, Ronald M. Is Wealth a Value? The Journal of Legal Studies, Vol. 9, No. 2, Change in the Common Law: Legal and Economic Perspectives (Mar., 1980), pp. 191-226. The University of Chicago Press. Disponível em:

http://www.jstor.org/stable/724129 Acesso em: 14/10/2010

Why Efficiency? 8 HOFSTRA L. REV. 563, 568-70 (1980).

ELLICKSON, Robert. Order without law: how neighbors settle disputes, Harvard University Press. (Hardcover 1991; Paperback 1994).

ELTZ, M.K.d.F. (2012). Uma abordagem da análise econômica do direito para os danos ambientais transfronteiriços. Economic Analysis of Law Review, 3(1), 4056. Acesso em: 20/04/2013. Disponível em:

http://portalrevistas.ucb.br/index.php/EALR/article/view/3\%20EALR\%2040/3\%20EAL $\underline{\mathrm{R} \% 2040}$

ERTMANN, Martha M. \& WILLIAMS, Joan C. Rethinking commodification; cases and readings in law and culture. Ed. by New York U. Pr. 2005.

FILHO, JOSÉ I.F.A.P. A teoria do inadimplemento eficiente (efficient breach theory) e os custos de transação. UC Berkeley: Berkeley Program in Law and Economics. (2007). Acesso em: 20/04/2013. Disponível em:

http://www.escholarship.org/uc/item/5tx002n8

FRIEDMAN, Lawrence M. Law, economics, and society. 39. Hofstra L. Rev. 487-496 (2011). Acesso em: 20/04/2013. Disponível em:

http://law.hofstra.edu/pdf/academics/journals/lawreview/lrv issues v39n03 bb-1-

friedman-final.pdf

FRIEDMANN, Daniel. The Efficient Breach Fallacy. The Journal of Legal Studies, Vol. 18, No. 1 (Jan., 1989), pp. 1-24 (tradução nossa). Disponível em:

http://www.jstor.org/stable/3085640 Acesso em : 01/05/2013.

GAROUPA, Nuno. A análise econômica do direito como instrumento de reforço da independência do judiciário. Revista de Direito Bancário e do Mercado de

Capitais. São Paulo. v.10. n.37. p.81-87. jul./set. 2007.

Combinar a Economia e o Direito: A Análise Económica do Direito.

Revista de Ciências Jurídicas e Econômicas. Publication Date: Sep 2009 Acesso em: 20/04/2013. Disponível em:

http://www.academia.edu/2824965/Combinar a economia eo direito a analise ec onomica do direito

GASPERIN, Antonio Augusto Tams. Pensar o passado e pensar o futuro. Direito e Economia entre o positivismo e a ética. Disponível em: <

http://jus2.uol.com.br/doutrina/texto.asp?id=6954 >. Acesso em 15 fev.2006.

GICO JR., Ivo T., Metodologia e Epistemologia da Analise Economica do Direito. (With English summary.). Economic analysis of law review. 2010;1(1):7-32.

Revista do Direito da UNISC, Santa Cruz do Sul, v.2, n. 46, p. 03-33, maio - ago. 2015. 
Acesso em: 20/04/2013. Disponível em:

http://portalrevistas.ucb.br/index.php/EALR/article/view/1460/1110

GOODWIN, Michele. The Free-Market Approach to Adoption: The Value of a Baby, 26 B.C. Third World L.J. 61 (2006), Acesso em 20/04/2013. Disponível em:

http://lawdigitalcommons.bc.edu/twli/vol26/iss $1 / 5$

GRESPAN, Jorge. A dialética do avesso. São Paulo: Xamã Editora,2003., cit. p.32.

HARDIN, Russell. The Morality of Law and Economics, Law and Philosophy, vol. 11, no. 4 (November), pp. 331-384. Acesso em 20/04/2013. Disponível em: http://www.nyu.edu/gsas/dept/politics/faculty/hardin/research/MoralityLaw.pdf

HEGEL, Georg W. F. Principios Da Filosofia Do Direito. São Paulo : Martins Fontes. 2000.

1ㄹ Edição, 1999.

Ciencia De La Logica. 2 volumes: Sudamericana Argentina.

Enciclopédia das ciências filosóficas em compêndio (1830), tradução de Paulo Meneses, São Paulo: edições Loyola, vol. I (A ciência da lógica), 1995. Janeiro: Renovar, 1989.

KASHIURA JR., Celso Naoto. Crítica da Igualdade Jurídica. Contribuição ao Pensamento Jurídico Marxista. São Paulo: Quartier Latin, 2009.

KOSIK, Karel. Dialética do Concreto. São Paulo: Editora Paz e Terra, 2002.

KUPFER, David. Economia Industrial: Fundamentos teóricos e práticos no Brasil. 2 ${ }^{a}$ edição. Rio de Janeiro: Campus, 2002, p. 268.

LANDES, Elisabeth M. \& POSNER, Richard, The Economics of the Baby Shortage, 7 J. Legal Studies. 323, 339-46 (1978).

LATIN AMERICAN AND IBERIAN LAW AND ECONOMICS ASSOCIATION. Acesso em: 20/04/2013. Disponível em: www.alacde.org.

LEISTER, Carolina. Economia Constitucional e Public Choice: a tendência estatal à expansão fiscal e seus limites institucionais. (abstract) Acesso em: 20/04/2013. Disponível em: http://portalrevistas.ucb.br/index.php/EALR/article/view/1456

LLEWELLYN, Karl. Jurisprudence: Realism in Theory and Practice. Chicago: University of Chicago Press, 1962, pp. 53-74.

LOPES, Jose Reinaldo de Lima. Direito e praxis social. Revista de Informação Legislativa. Brasilia. v.27. n.105. p.191-202. jan./mar. 1990. Acesso em 20/04/2013. Disponível em:

http://www2.senado.gov.br/bdsf/bitstream/id/175756/1/000448505.pdf

Revista do Direito da UNISC, Santa Cruz do Sul, v.2, n. 46, p. 03-33, maio - ago. 2015. 
The traditional dialogue between Law \& Economics.

Revista DIREITO GV;Especial 1, 2005 Acesso em 20/04/2013. Disponível em: http://bibliotecadigital.fgv.br/dspace/bitstream/handle/10438/9662/Jos\%C3\%A9\%20R einaldo\%20de\%20Lima\%20Lopes.pdf?sequence=1

LÓPEZ, Jesús. Praxis y normatividad como criterio de cientificidad de la ciencia jurídica. DOXA: Cuadernos de Filosofía del Derecho. Alicante. n.23. p.503-60. 2000. Acesso em 20/04/2013. Disponível em: http://rua.ua.es/dspace/bitstream/10045/10260/1/doxa23 20.pdf

MACKAAY, Ejan. History of Law and Economics. Enciclopédia L\&E Acessado em 1 dez.2012. Disponível em: http://encyclo.findlaw.com/0200book.pdf

MARX, Karl \& ENGELS, Friedrich. A sagrada família. Tradução e notas de Marcelo Backes, São Paulo: Boitempo editorial, 2003.

A Ideologia alemã. tradução de José Carlos Bruni e Marco Aurélio Nogueira, São Paulo: Hucitec, 1984.

MARX, Karl. Contribuição Para a Crítica da Economia Política. Lisboa: Editorial Estampa, 1973.

Boitempo editorial, Vol.1, 2013.

O capital. Tradução de Rubens Enderle. São Paulo:

MELO, Tarso de. Direito e ideologia: um estudo a partir da função social da propriedade rural. São Paulo: Expressão popular, 2009

MIAILLE, Michel. Uma introdução crítica ao direito. Trad. Ana Prata, Lisboa: Moraes Editora, 1979

PACHUKANIS, Eugeny B. A teoria geral do direito e o marxismo, trad. Paulo Bessa, Rio de Janeiro: Renovar, 1989.p. 84

POLINSKY, A. Mitchell, An Introduction to Law and Economics Boston: Little, Brown \& Company, 1989.

PONTES, José Antonio Siqueira. Some advances in legal practical reason: for a progressive dialogue with contemporary hermeneutics. 25th IVR World Congress:

Law, Science and Technology (105) Publisher: Goethe-Univ: Frankfurt am Main Conference Proceeding. 2011/2. Acesso em 20/04/2013. Disponível em: http://digital-b.ub.uni-frankfurt.de/frontdoor/index/index/docld/24963

POSNER, Eric A. Análise econômica do direito contratual após três décadas: sucesso ou fracasso? (primeira parte). Revista de Direito Público da Economia. Belo Horizonte. v.6. n.23. p.75-108. jul./set. 2008. Acesso em: 20/04/2013. Disponível em: http://bdjur.stj.jus.br/xmlui/bitstream/handle/2011/28538/analise economica direito posner parte1.pdf?sequence $=4$

Revista do Direito da UNISC, Santa Cruz do Sul, v.2, n. 46, p. 03-33, maio - ago. 2015. 
Análise econômica do direito contratual após três décadas: sucesso ou fracasso? (segunda e última parte). Revista de Direito Público da Economia. Belo Horizonte. v.6. n.24. p.125-55. out./dez. 2008. Acesso em: 20/04/2013. Disponível em:

http://bdjur.stj.jus.br/xmlui/bitstream/handle/2011/28538/analise economica direito posner parte2.pdf? sequence $=5$

Fault in Contract Law. Eric A. Posner. Michigan Law

Review. Vol. 107, No. 8, (Jun., 2009), pp. 1431-1444. Acesso em: 20/04/2013.

Disponível em: www.law.uchicago.edu/files/files/396.pdf

. Law and Social Norms. Harvard Univertity Press. 2002, p.4

POSNER, Richard \& PARISI, Francesco, Law and Economics: An Introduction. in Law and Economics, Vol. 1: Theoretical and Methodological Foundations. 1997: Mark Blaug Editor.

POSNER, Richard A. The Law and Economics Movement American Economic Review, 77 (2), May, 1987,p. 1-13.

Pub. Pol'y 85 (1985)

. Wealth Maximization Revisited, 2 Notre Dame J.L. Ethics \&

1st. Edition.

Economic Analysis of Law, Little, Brown \& Company, 1973.

Wealth maximization and judicial decision-making.

International Review of Law and Economics, Volume 4, Issue 2, December 1984, Pages 131-135, acesso em 20-04-2013. Disponível em:

http://www.sciencedirect.com/science/article/pii/0144818884900024

$\mathrm{REICH}$, Robert B. Supercapitalismo - Como o capitalismo tem transformado os negócios, a democracia e o cotidiano. Rio de Janeiro, Elsevier, 2008.

RIESCO, Manuel. Social Policy in a Development Context Series. Latin America. EBOOK. Palgrave Macmillan, 2013, p. 38. http://dx.doi.org/10.1057/9780230625259.

SCHÄFER, Hans-Bernd \& OTT, Claus. The dichotomy between property rules and liability rules: Experiences from German Law (2008). German Working Papers in Law and Economics, Paper 12, Vol. 2008, 21 Seiten. Acesso em: 20/04/2013. Disponível em: http://www.erasmuslawreview.nl/files/ELR specialissue 03.pdf

SWEDBERG, Richard. The case for an economic sociology of Law. Cornell University. Theory and Society (impact factor: 1.06). 01/2003; 32(1):1-37. Acesso em: 20/04/2013. Disponível em:

http://www.soc.cornell.edu/faculty/swedberg/2003\%20The\%20Case\%20for\%20an\%2 0Economic\%20Sociology\%20of\%20Law.pdf

Revista do Direito da UNISC, Santa Cruz do Sul, v.2, n. 46, p. 03-33, maio - ago. 2015. 
USHER, Dan. The Coase theorem is tautological, incoherent or wrong. Economics Letters 61 (1998) 3-11. Acesso em 20-04-2013. disponível em

http://www.sfu.ca/ allen/usher.pdf

VAN DEN BERGH, Roger. Introduction: The Impact of Guido Calabresi on Law and Economics Scholarship (November 2, 2009). Erasmus Law Review, Vol. 1, No. 4, 2008. Acesso em: 20/04/2013. Disponível em:

http://www.erasmuslawreview.nl/files/ELR specialissue 01.pdf

VÁSQUEZ, Adolfo S. Filosofia da Práxis. São Paulo: Expressão Popular, 2007

VELOSO, Sílvia Mechelany \& CATEB, Alexandre Bueno. Análise econômica do indadimplemento contratual oportunista versus $o$ inadimplemento eficiente (efficient breach). Disponível em:

http://www.revistadir.mcampos.br/PRODUCAOCIENTIFICA/artigos/alexandrebuenoc atebsilviamechelanyanaliseeconomica.pdf

WALLER, Spencer Weber. The Law and Economics Virus, 31 Cardozo L. Rev. 367, November (2009). Acesso em: 20/04/2013. Disponível em:

http://lawecommons.luc.edu/cgi/viewcontent.cgi?article $=1121 \&$ context=facpubs

ZYLBERSZTAJN, Decio ; SZTAIN, Rachel. Análise Econômica do Direito e das Organizações. In: Direito \& Economia: Análise Econômica do Direito e das Organizações. Editora Campus, 2005.

Revista do Direito da UNISC, Santa Cruz do Sul, v.2, n. 46, p. 03-33, maio - ago. 2015. 